\title{
Lung compartmentalization of inflammatory biomarkers in COVID-19-related ARDS
}

\author{
Youenn Jouan 1,2,3,4 $\mathbb{0}$, Thomas Baranek ${ }^{1,2}$, Mustapha Si-Tahar ${ }^{1,2}$, Christophe Paget ${ }^{1,2}$ and Antoine Guillon ${ }^{1,2,3^{*}}$
}

\section{Dear Editor,}

We read with great interest the article of Bendib et al. published in Critical Care [1], in which they systematically assessed inflammatory mediators in pneumoniarelated ARDS, both in airways and blood compartments. The authors observed a lung compartmentalization of inflammatory mediators, with important heterogeneity in the bronchoalveolar lavage fluid-to-serum concentration ratios across the mediators screened. The concept of compartmentalization of inflammation has already been formulated in pneumonia [2], and issues raised by assessing lung inflammation using blood inflammatory markers has also been highlighted, as well as the subsequent limitations of these biomarkers for bedside management [3]. However, we believe that it is critical to examine it further in ARDS, in this COVID-19 era. Indeed, since the beginning of the pandemic, most of the studies exploring immune dysregulation during COVID-19 were nevertheless based on data obtained only from blood, not because this is the most relevant compartment, but because it is the most easily accessible.

In complement to the work of Bendib et al., we evaluated coincident inflammatory mediators in blood and respiratory fluids (endotracheal aspirates [ETA]) of 21 critically ill COVID-19 patients with ARDS requiring mechanical ventilation, within $48 \mathrm{~h}$ of their admission in ICU. As observed by Bendib et al., we found an

This comment refers to the article available online at https://doi.org/10.1186/ s13054-020-03427-y.

*Correspondence: antoine.guillon@univ-tours.fr

${ }^{3}$ Service de Médecine Intensive Réanimation, Centre Hospitalier Régional Universitaire, 2 Bd Tonnellé, 37044 Tours Cedex 9, France

Full list of author information is available at the end of the article increased ETA-to-blood concentration ratio for IL-8, the cytokine for which concentration was the most compartmentalized to the lung. However, in our COVID-19 ARDS cohort, the median (quartile 1; quartile 3) ratio was highly elevated: 7355 (1959; 22433), compared to 20 in the study of Bendib et al. Moreover, ETA to blood concentration ratios of IL-1RA, IL-6, IFN- $\gamma$, TNF- $\alpha$ and CXL10 were also highly elevated (Fig. 1), at a higher level than those reported by Bendib et al. for ARDS without shock. Thus, during COVID-19-driven ARDS -and even compared to non-COVID-pneumonia-related ARDSinflammation appears highly compartmentalized to the lungs. These results are in line with publications reporting relatively low levels of systemic inflammatory mediators compared to other conditions requiring ICU $[4$, 5]. Taken together, these data challenge the concept of "systemic cytokine-storm" that has been employed to describe immune dysregulation during severe COVID19. Consequently, in our quest of identifying reliable biomarker in pneumonia-induced ARDS -whether COVID or not-, lungs should not be excluded.

\section{Authors' response \\ Inès Bendib5, and Nicolas de Prost ${ }^{5,6^{*}}$ \\ *Correspondence: nicolas.de-prost@aphp.fr \\ ${ }^{5}$ Service de Médecine Intensive Réanimation, Hôpitaux Universitaires Henri Mondor, Assistance Publique-Hôpitaux de Paris, 51, Avenue du Maréchal de Lattre de Tassigny, 94010 Créteil Cedex, France \\ ${ }^{6}$ Groupe de Recherche Clinique CARMAS, Faculté de Santé de Créteil, Université Paris Est Créteil, 94010 Créteil Cedex, France.}

\section{Interleukin-8 is highly compartmentalized to the lungs in COVID-19 and non-COVID-19 ARDS}

We thank Jouan et al. for their letter related to our recently published article [1]. Although serum original author(s) and the source, provide a link to the Creative Commons licence, and indicate if changes were made. The images or other third party material in this article are included in the article's Creative Commons licence, unless indicated otherwise in a credit line to the material. If material is not included in the article's Creative Commons licence and your intended use is not permitted by statutory regulation or exceeds the permitted use, you will need to obtain permission directly from the copyright holder. To view a copy of this licence, visit http://creativecommons.org/licenses/by/4.0/. The Creative Commons Public Domain Dedication waiver (http://creativeco mmons.org/publicdomain/zero/1.0/) applies to the data made available in this article, unless otherwise stated in a credit line to the data. 


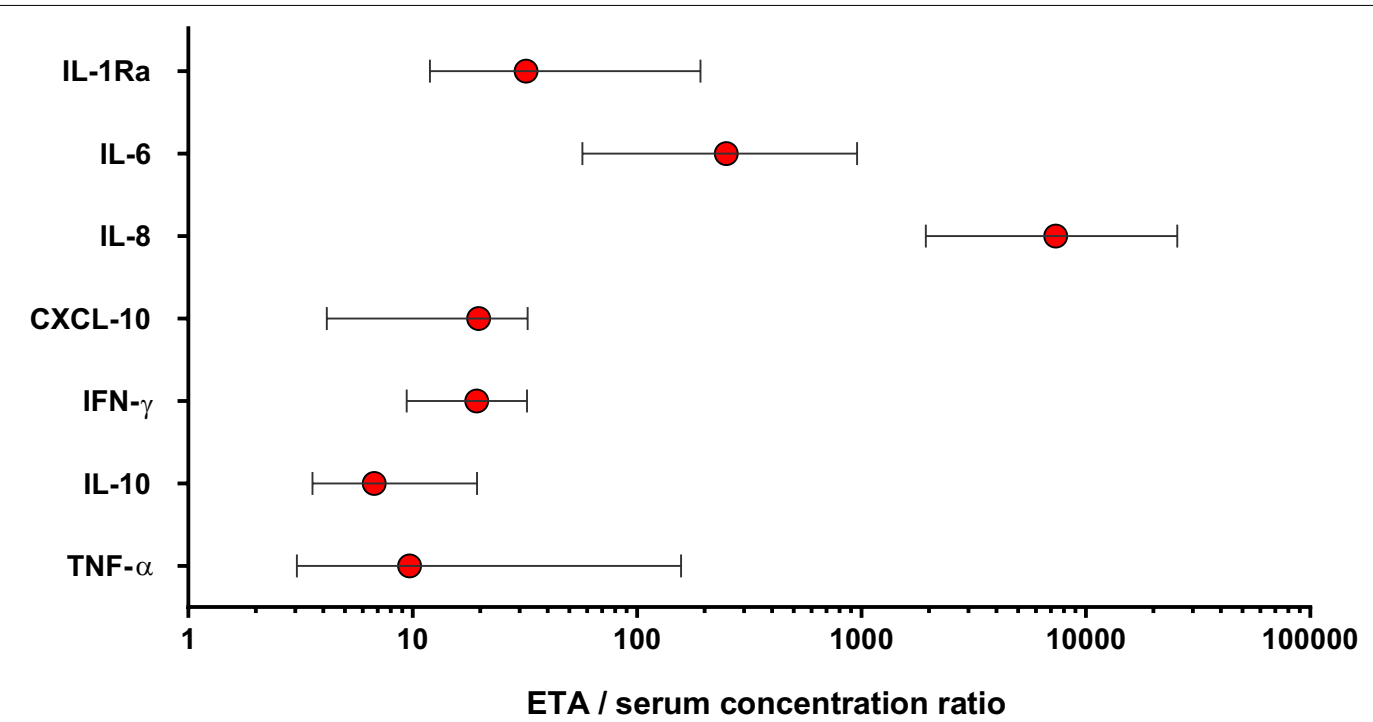

Fig. 1 Endotracheal aspiration (ETA)-to-serum concentration ratio of inflammatory biomarkers in COVID-19-related ARDS. Inflammatory mediators (IL-1Ra, IL-6, IL-8, IL-10, CXCL-10, IFN-y, TNF-a) were measured in blood (serum) and supernatants of endotracheal aspirations with the Bio-Plex Pro Human cytokines panel (Bio-Rad) in a multiplex fluorescent bead assay (Luminex), according to the manufacturer's instructions. The density ratio of endotracheal aspiration $(\mathrm{g} / \mathrm{mL})$ was 1:1. Circles and bars represent median values and interquartile range respectively

biomarkers can depict specific profiles in patients with ARDS associated with COVID-19 and other diseases [6], the degree of cytokine release is markedly lower in critically ill COVID-19 than in other disorders associated with elevated cytokines (e.g., non-COVID-19 ARDS, sepsis, CAR-T cell therapy) [7]. Assessing the production of lung borne cytokines might thus be particularly relevant in COVID-19 patients. Consistent with our results in non-COVID-19 ARDS patients, Jouan et al. showed in patients with severe SARS-CoV-2 infection that the highest endotracheal aspirates (ETA) to blood concentration ratio was observed for interleukin-8 (IL-8). The authors pointed out some differences regarding the magnitude of the concentration gradient they measured (median value of the ETA to blood ratio of IL-8: 7355) and ours, which included only non-COVID-19 patients with pneumoniaassociated ARDS (median value of the broncho-alveolar lavage (BAL) to serum ratio of IL-8: 21). Such magnitude difference might be due to the following factors: (1) a dilution of BAL fluid samples; (2) differences in IL-8 concentrations in proximal vs. distal airways and hypothetically, (3) higher IL-8 lung to blood concentration ratios in COVID-19 than in non-COVID-19 patients. ETA to blood concentration ratios of other cytokines, including interleukin- 6 were also highly elevated in COVID-19 patients in the letter of Jouan et al. However, the clinical implications of these findings need to be investigated. Further studies will be needed to assess whether measuring lung to blood concentration ratios of selected biomarkers could help target patients most likely to benefit from immunomodulating drugs targeting cytokine pathways [8].

\section{Acknowledgements \\ Not applicable.}

\section{Authors' contributions}

$Y G, T B, M S T, C P$ and $A G$ were involved in drafting the manuscript. All authors read and approved the final manuscript.

\section{Funding}

No funding was used for this study.

\section{Availability of data and materials}

The datasets used and/or analyzed for this research letter are available from the corresponding author on reasonable request.

\section{Ethics approval and consent to participate}

All patients or their next of kin gave consent for participation in the study cited in this research letter. This work was part of an ongoing study exploring immune response during community-acquired pneumonia (ClinicalTrial.gov identifier: NCT03379207). The study was approved by the ethic committee "Comité de Protection de Personnes lle-de-France 8 " under the agreement number 2017-A01841-52, in accordance with the national laws.

\section{Consent for publication}

Not applicable.

\section{Competing interests}

No competing interests to declare.

\section{Author details}

${ }^{1}$ INSERM, Centre d'Etude des Pathologies Respiratoires (CEPR), UMR 1100, Tours, France. ${ }^{2}$ Faculté de Médecine de Tours, Université de Tours, Tours, France. ${ }^{3}$ Service de Médecine Intensive Réanimation, Centre Hospitalier Régional Universitaire, 2 Bd Tonnellé, 37044 Tours Cedex 9, France. ${ }^{4}$ Service de chirurgie cardiaque et de réanimation chirurgicale cardio-vasculaire, Centre Hospitalier Régional Universitaire, Tours, France. 
Received: 29 January 2021 Accepted: 18 February 2021

Published online: 24 March 2021

\section{References}

1. Bendib I, Beldi-Ferchiou A, Schlemmer F, Surenaud M, Maitre B, Plonquet A, et al. Alveolar compartmentalization of inflammatory and immune cell biomarkers in pneumonia-related ARDS. Crit Care. 2021;25:23. https://doi. org/10.1186/s13054-020-03427-y

2. Quinton $L J$, Walkey AJ, Mizgerd JP. Integrative physiology of pneumonia. Physiol Rev. 2018;98:1417-64.

3. García-Laorden MI, Lorente JA, Flores C, Slutsky AS, Villar J. Biomarkers for the acute respiratory distress syndrome: how to make the diagnosis more precise. Ann Transl Med. 2017;5:283-93.

4. Riva G, Nasillo V, Tagliafico E, Trenti T, Comoli P, Luppi M. COVID-19: more than a cytokine storm. Crit Care. 2020;24:1-3.

5. Kox M, Waalders NJB, Kooistra EJ, Gerretsen J, Pickkers P. Cytokine levels in critically III patients with COVID-19 and other conditions. JAMA. 2020;324:1565-7.
6. Hue S, Beldi-Ferchiou A, Bendib I, Surenaud M, Fourati S, Frapard T, et al. Uncontrolled innate and impaired adaptive immune responses in patients with COVID-19 ARDS. Am J Respir Crit Care Med. 2020;202:1509-19.

7. Leisman DE, Ronner L, Pinotti R, Taylor MD, Sinha P, Calfee CS, et al. Cytokine elevation in severe and critical COVID-19: a rapid systematic review, meta-analysis, and comparison with other inflammatory syndromes. Lancet Respir Med. 2020;8:1233-44.

8. Convertino I, Tuccori M, Ferraro S, Valdiserra G, Cappello E, Focosi D, Blandizzi C. Exploring pharmacological approaches for managing cytokine storm associated with pneumonia and acute respiratory distress syndrome in COVID-19 patients. Crit Care. 2020;24:331.

\section{Publisher's Note}

Springer Nature remains neutral with regard to jurisdictional claims in published maps and institutional affiliations.
Ready to submit your research? Choose BMC and benefit from:

- fast, convenient online submission

- thorough peer review by experienced researchers in your field

- rapid publication on acceptance

- support for research data, including large and complex data types

- gold Open Access which fosters wider collaboration and increased citations

- maximum visibility for your research: over $100 \mathrm{M}$ website views per year

At BMC, research is always in progress.

Learn more biomedcentral.com/submissions 